\title{
A review of private investment in Tanzania's power generation sector
}

\author{
Anton Eberhard ${ }^{1 *}$, Katharine Gratwick ${ }^{2}$, Laban Kariuki ${ }^{3}$ \\ 1 Graduate School of Business, University of Cape Town, 9 Portswood Road, Greenpoint, 8015, Cape Town, \\ South Africa \\ 2 Independent consultant, Houston, Texas, United States of America \\ 3 Independent consultant, Dar-es-Salaam, Tanzania
}

\begin{abstract}
This study investigates recent developments in Tanzania's electric power generation to understand how to facilitate investment in the sector. Interviews were conducted with key public and private stakeholders; utility data was analysed and critical secondary source documents were reviewed. All interview data was triangulated to ensure integrity of findings. It was concluded that investment in the sector is suboptimal due to a lack of coherent planning; of processes related to contract negotiation; and of a commitment to contract with independent power projects. Research and analysis is limited to generation, but there are also implications for the distribution sector. The value of the findings extends beyond Tanzania across Africa and to other developing regions, where countries struggle to attract investment into electric power generation.
\end{abstract}

Keywords: private power investment; East Africa; regulation; power sector reform

Journal of Energy in Southern Africa 29(2): 1-11

DOI: http://dx.doi.org/10.17159/2413-3051/2018/v29i2a4389

Published by the Energy Research Centre, University of Cape Town ISSN: 2413-3051 http://journals.assaf.org.za/jesa

Sponsored by the Department of Science and Technology

\footnotetext{
* Corresponding author: Tel: +27 21406 1361;

email: anton.eberhard@gsb.uct.ac.za
} 


\section{Introduction}

Tanzania has a vast array of conventional and renewable energy resources, and yet the country struggles to generate sufficient power to fuel growth and development. In 2016, it had approximately 1 500 megawatts (MW) in installed generation. Network failures undermined what little power is produced. As a result, approximately 46 percent of the nation's total power consumption was from offgrid, self-generation (averaging USD 0.35/kWh) (National Key Result Area Energy, 2013). What has prevented Tanzania from harnessing more of its domestic resources in an economically efficient way, and what can be done differently going forward? There appear to be three key elements that directly affect Tanzania's electricity supply industry and generation procurement: coherent and up-todate planning; the planning and procurement nexus, including the allocation of public and private generation projects; and a lack of sustained commitment to private sector investment and competitive bidding practices.

The first section of the paper provides a brief overview of the drivers for power sector reform and their results, followed by a description of how the Tanzanian sector developed. Then the current structure and capacity is described, together with prices and plant performance data. In subsequent sections, the analysis focuses on how capacity was procured and financed in both public and independent power projects (IPPs), as well as future plans. Finally, conclusions are drawn about fundamental elements that have contributed to and detracted from power generation development in Tanzania, and about what is needed going forward.

\section{Power sector reform: Impetus and results}

At the beginning of the 1990s, nearly all major power generation in Africa was financed from public coffers, including concessionary loans from development finance institutions. These publicly financed generation assets were considered one of the core elements in state-owned, vertically integrated power systems. In the early 1990s, however, a confluence of factors brought about a significant change. With the main drivers identified as insufficient public funds for new generation and decades of sub-standard performance by state-run utilities, African countries began to adopt a new 'standard' model for their power systems, influenced by pioneering reformers in the United States of America, the United Kingdom, Chile and Norway (Clark et al., 2005; Gratwick \& Eberhard, 2008). Urged on by multilateral and bilateral development institutions like the World Bank, which largely withdrew from funding state-owned projects, several countries adopted plans to unbundle their power systems and introduce private participation and competition (Eberhard \& Gratwick, 2011). IPPs - name- ly, privately financed, greenfield generation, supported by non-recourse or limited recourse loans, with long-term power purchase agreements (PPAs) with the state utility or another off-taker - became a priority within overall power sector reform (World Bank, 1993: 45, 51; World Bank and USAID, 1994: $1)$. The IPPs were considered a solution to persistent supply constraints and could also potentially serve to benchmark state-owned supply and gradually introduce competition (APEC Energy Working Group, 1997). The IPPs could be undertaken before sector unbundling. An independent regulator was also not a prerequisite, since the PPA laid down a form of regulation by contract. (More information on the drivers of power sector reform in Africa is available in a supplementary file. ${ }^{1}$ )

With the original drivers for market reform still present, especially in Tanzania, private sector involvement appears inevitable in the future. Subsequent sections delve in to Tanzania's power sector present and recent past to shed light on how to improve performance and investment in the country's generation.

\section{Tanzania's electricity sector: An overview 3.1 Power sector reforms}

The vertically integrated, state-owned Tanzania Electric Supply Company (TANESCO) performed adequately in the 1960s and 1970s. In the 1980s, electric supply and distribution began to deteriorate and has remained poor ever since. Repeated attempts at reform, targeting the utility's poor performance. started in the early 1990s. In 1992, a National Energy Policy was formulated that opened the sector to private participation, including a provision to encourage private electricity generation and distribution in areas where TANESCO had not established a public power supply system. The next year, bids were invited for the country's first IPPs. Following this push, in 1997, TANESCO was earmarked for privatization. Under pressure from the World Bank and International Monetary Fund, these efforts intensified from 1999, and included a doubling of nominal tariffs.

By 2001, with electricity costs relatively high, the quality and reliability of supply still poor, and the financial standing of the state utility persistently weak, attention focused on TANESCO's management. In that year, the government of Tanzania reconstituted TANESCO's board and initiated a management contract that was set up to last two years, starting in 2002 but ended up spanning four years (Clark et al., 2005; Kapika \& Eberhard, 2013). While TANESCO's balance sheet improved under the management contract, specifically because of better collection, the quality and reliability of supply and the rate of new electricity connections did not increase materially, mainly because of underinvestment (Ghanadan and Eberhard, 2007: 
23). Then, in 2005, an incoming administration reversed plans and delisted TANESCO from privatisation, in direct opposition to an underlying objective of the management contract. In 2006, the government announced that the management contract would not be extended, a decision that met with wide public approval.

Two years later, in 2008, the Electricity Act was passed, updating the 1957 Electricity Ordinance Amendment, which had until then governed the sector. With respect to the structure of the electricity industry, Clause 4(1) of the Act states:

The Minister shall provide supervis[ion] and oversight in the electricity supply industry and shall in that respect . . . take all measures necessary to reorganise and restructure the electricity supply industry with a view to attracting private sector and other participation, in such parts of the industry, [in] phases or time frames as he deems proper.

After nearly two decades of reforms characterised by a fluctuating commitment to private sector participation, the Electricity Act of 2008 appeared to signal a renewal of the government's commitment to reform the sector, albeit in part at the insistence of the donor community (as had been the case for the duration of the reforms).

In 2011-12, however, actual practices on the ground departed from this policy commitment, with the procurement and installation of many emergency power plants (EPPs), with a combined capacity of $205 \mathrm{MW}$, and a push for four state-owned power projects. While privately owned, the EPPs worked contrary to the goals of competition and reform, and aggravated TANESCO's financial situation again (Kapika \& Eberhard, 2013; Eberhard et al., 2016). TANESCO's net loss in 2013 was USD 295 million (up from USD 112 million in 2012). Meanwhile, accumulated losses as of 2013 stood at USD 915 million (up from USD 620 million in 2012) (United Republic of Tanzania Audit Office 2013: 27).

The 'Big results now' (BRN) initiative, which came into effect in 2013, was rooted in the 2008 Electricity Act, which reaffirmed the goal of unbundling and privatising the sector. According to $\mathrm{BRN}$, the mandate of the planning framework, under Tanzania's Development Vision 2025, was to transform Tanzania's future electricity landscape. By 2025, Tanzania was expected to have installed 10 $000 \mathrm{MW}$, more than six times its present capacity, which would represent a radical departure from past supply shortages (MEM 2014: i). It is important to note, however, that the BRN targets were abandoned by the government of President John Magufuli, who was voted into office in October 2015. Targets were scaled back to 5,000 MW by 2020 and 7000 MW by 2025.
In 2014, PriceWaterhouseCoopers also provided strategic advice related to the unbundling of TANESCO. At the time of writing, however, there had been virtually no progress made in unbundling the sector, with delays attributed to associated delays in the asset evaluation and a lack of clear oversight of the process at the ministry of energy. Other challenges for the sector include a lack of transparency, as discussed in the context of two high-profile cases (Independent Power Tanzania Ltd (IPTL) and Richmond/Dowans) in the supplementary file, and what private investors have repeatedly described as the favouring of publicly funded projects over private investment. Future developments are likely to see all private projects undertaken as public-private partnerships (PPPs); meanwhile, all new long-term projects in recent years were built and owned by TANESCO (despite, it should be emphasised, TANESCO's precarious financial situation) rather than the private sector. Furthermore, despite regulatory statutes that encourage a competitive approach, competitive arrangements were seldom the norm in doing business with the private sector.

What factors explain the country's shifts toward and away from private investment and reform measures; and the disconnection between adopted policy and actual practices on the ground? Part of this disconnect may be attributed to the fact that the numerous state actors involved are not united in their policy positions and approaches, and various factions have at times worked against one another (Kapika \& Eberhard, 2013; Eberhard et al., 2016).

Finally, it is worth noting that, while feed-in tariffs are under discussion, there are at present no specific incentives for large-scale renewable projects.

\subsection{The sector's structure and institutions}

Notwithstanding the ambitious reforms envisioned for the electricity sector, its present structure (Figure 1) continues to be characterised by a poor-performing, vertically integrated, state-owned utility (whose attempts to contract IPPs are sporadic and not always successful), and the prominence of nontransparent deals. The government, through the Ministry of Energy and Minerals (MEM), is responsible for formulating energy policy. A statute dictates that the regulation of the sector be conducted by an independent regulatory agency, the Energy and Water Utilities Regulatory Authority (EWURA). However, as will be discussed in more detail, EWURA has not always been emboldened to carry out the regulation that is its mandate.

At the industry level, all the defining features of a hybrid electricity market are visible (Gratwick and Eberhard, 2008). TANESCO dominates the sector, while IPPs (Songas and Independent Power Tanzania ) provide additional generation capacity, 


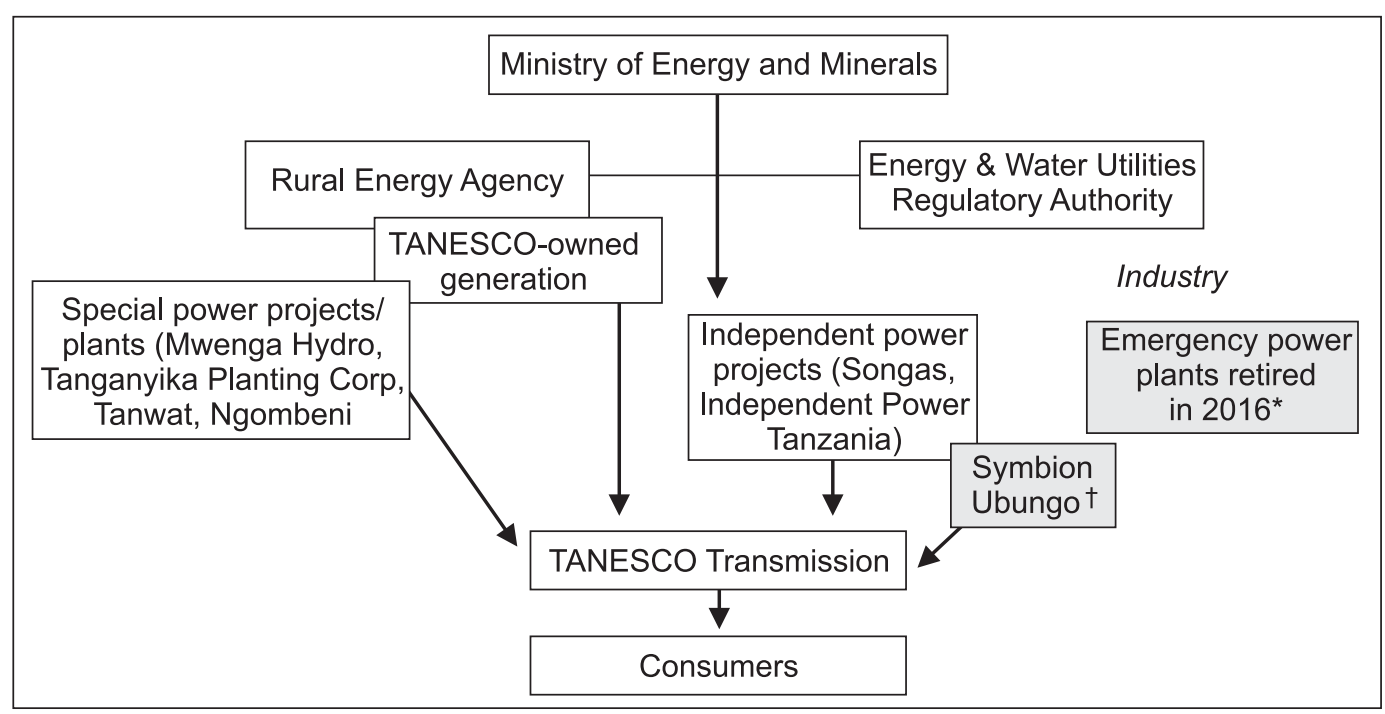

Notes:

* All EPPs phased out as of 2016. TANESCO = Tanzania Electric Supply Company

$\dagger$ Symbion Ubungo signed PPA in 2016 though at the time of writing no power was being purchased, as discussed in subsequent sections.

Figure 1: Overview of Tanzania's electricity sector, 2016.

together with Mwenga hydropower, Tanganyika Planting Corporation, Tanwat, and Ngombeni through small power projects. While TANESCO remains the dominant player, Songas (see supplementary file) supplies between 20 and 25 percent of grid electricity, as seen in the next section.

\subsection{Power sector processes}

TANESCO and EWURA have advisory and support roles, while the MEM is responsible for power planning. This has largely been an ad hoc arrangement to address performance issues within the MEM and across the planning process. It presents several challenges, including the fact that TANESCO takes part in sector planning, while simultaneously retaining an interest in building its own new power stations. The planning process is characterised by politics rather than impartial and sound (near- and longterm) decisions based on outside data sources. The Electricity Act of 2008 allocated the power system master plan to an independent system operator. At the time of writing this had not been established, though the most recent Reform Strategy and Roadmap stipulated that it should be done between July 2014 and June 2015 (MEM, 2014: 42). Noteworthy in this context is that in the past ten years the MEM has seen five permanent secretaries, five ministers, and several different deputy ministers - a turnover that has had serious ramifications for the planning and associated execution and coordination processes.

Several master plans and strategies have been produced over the years, but they have quickly obsolesced, and it would appear that they have not directly informed procurement decisions. The pre- sent Power Sector Master Plan (2012) was initially bolstered by BRN (2013), though BRN has since been scrapped and a new plan (supported by the Japan International Cooperation Agency, JICA) is presently under preparation, though that too is delayed (MEM, 2013: 11; NKRA Energy, 2013: 458).

While TANESCO has built some generation capacity, as described below, this has been funded by the government; the utility has scant resources to finance its own future projects.

Meanwhile, numerous prospective IPP developers have entered into memoranda of understanding with the MEM, but the ministry has limited capacity to assess value for money or undertake the negotiations necessary to bring these to fruition. As a result, very few projects have materialised, as will be highlighted in the discussion of IPPs. Those that have been negotiated have been slow to reach financial close or commissioning. Furthermore, there has been limited application of international competitive tendering.

The Electricity Act gives EWURA the power to approve the initiation of procurement of power projects. These powers have been further defined under the Electricity (Initiation of Power Procurement) Rules, with the overarching goal of discouraging unsolicited proposals that fall outside the power system master plan and are not financially viable for the state (Electricity Act [CAP 131]; see supplementary file for more detail). EWURA is supposed to review all projects in Tanzania, a principle that is enshrined in the Electricity Rules; however, it is not clear that the agency is sufficiently equipped to carry out this task. While the legislation came into 
effect in January 2015, negotiations over unsolicited proposals carried on in ensuing months, including with the Kilwa IPP, a 308 MW gas-fired project that initially was highlighted by the MEM among near-term projects, and introduced by retired public servants and one foreign investor. As of Q3-2016, there is no progress to report on Kilwa.

\subsubsection{Gas: Challenges and potential}

The discovery of significant offshore gas to the south is among the most positive developments in Tanzania in recent years (Table 1). Contingent resources are estimated at 29 trillion cubic feet (Tcf), although estimates of close to $50 \mathrm{Tcf}$ have been reported.

\begin{tabular}{|c|c|c|c|}
\hline Field & $\begin{array}{l}\text { Discovery } \\
\text { date }\end{array}$ & $\begin{array}{l}\text { GIIP } \\
(T c f)^{*}\end{array}$ & $\begin{array}{l}\text { Proven } \\
\text { (Tcf) }\end{array}$ \\
\hline Songo Songo & 1974 & 2.5 & 0.880 \\
\hline Mnazi Bay & 1982 & $3-5$ & 0.262 \\
\hline Mkuranga & 2007 & 0.2 & 0.2 \\
\hline Kiliwani & 2008 & 0.07 & 0.027 \\
\hline Mtwara-Ntorya & 2012 & 0.178 & - \\
\hline Deep Sea & $2010-14$ & $\begin{array}{l}35.10(2013) \\
49.30(2016)\end{array}$ & - \\
\hline Total & & $\begin{array}{l}57.25 \text { Tcf (assum- } \\
5 \text { Tcf Mnazi Bay) }\end{array}$ & Unknown \\
\hline
\end{tabular}

Note: *.GIIP = gas initially in place, not proven reserves; $\mathrm{Tcf}=$ trillion cubic feet.; $-=$ not available.

In the near term, domestic gas-to-electricity projects are making use of onshore reserves in a broader push to diversity resources (including hydro, gas, coal, geothermal, solar and wind). Thereafter, the priority for Tanzania is to develop two liquefied natural gas (LNG) trains from deep-sea gas for export, entailing a commitment of $14 \mathrm{Tcf}$ of gas. In the long term, at least two further LNG trains are planned. However, offshore gas will not flow without an established export market, as it is too expensive and the volumes too low in the country to justify it. Until recently, the absence of relevant planning and timely implementation (including the development of pipeline and gas-processing infrastructure), along with a weak investment climate, prevented Tanzania from exploiting its gas potential. Instead, the country plugged shortages with imported and costly diesel-fired EPPs, which have since been phased out. The high costs of engaging and fueling a fleet of EPPs with imports in the past five years (for 2012 alone, EPP costs were estimated to be USD 320 million) effectively bankrupted TANESCO. Government support for TANESCO in this period was sporadic, and insufficient to keep it liquid. As a result, TANESCO stopped paying the IPPs, EPPs, and some of their fuel suppliers. With funding obtained from donors and commercial lenders, TANESCO is beginning to recover from this financial shock, but until recently owed large arrears to the sector (estimated to be up to USD 300 million).

The government is presently finalising its natural gas utilisation master plan, which is expected to be updated annually.

\subsection{Installed generation capacity}

As of 2016, Tanzania's total installed generation capacity was $1.474 \mathrm{MW}$, including $561 \mathrm{MW}$ of hydropower (38 percent), $717 \mathrm{MW}$ of natural-gasfired power plants (49 percent), and $495 \mathrm{MW}$ of liquid-fuel power plants (12 percent), of which 53.6 MW is off-grid (Table 2). A further small amount less than 1 percent of Tanzania's power - is imported from Uganda, Zambia, and Kenya. The current profile is dramatically different from that of the recent past. Between 1980 and 2000, much of the supply was state-owned hydropower.

Several additional observations are noteworthy. Four of the abovenoted EPPs/rentals (Aggreko Tegeta, Aggreko Ubungo, Symbion Arusha, Symbion Dodoma) have since been retired; however, during their tenure they made a significant impact on TANESCO's balance sheet and became synonymous with 'private power'. The fifth EPP, Symbion Ubungo is, as of end 2016, producing no power (though the facilities are still in place and it is included in total capacity above). They were included above to draw attention to their recent historical role, which influenced the power landscape and also the perception of private power.

\subsection{Power sector performance}

The performance of the sector is also critical to evaluating both private and public-sector generation. This analysis has implications for the revised goal of 5000 MW by 2020 and sector unbundling. It should be reiterated at the outset that, while TANESCO is breaking away from its spiral of debt, its financial situation has been dire (with arrears running into the millions of dollars), which has been a significant barrier to attracting new investors through transparent channels.

\subsubsection{Electricity produced}

The actual units generated in 2015 reflect the dominant role of TANESCO (58 percent), albeit also the important role IPPs continue to play, with Songas IPP the largest contributor (23 percent of the total 33 percent in IPP electricity production).

\subsubsection{Electricity prices}

The average 2016 cost per kilowatt-hour was TZS $272 / \mathrm{kWh}$ (which reflects a tariff reduction from 
Table 2: Grid-connected capacity in Tanzania, as of 2016. (Source: MEM 2013: 16; data received from TANESCO: November 14, 2014; January 9, 2015; EWURA: October 20, 2016.)

\begin{tabular}{|c|c|c|c|c|c|}
\hline Name & Ownership & Installed & Retire & Fuel & $\begin{array}{c}\text { Installed capacity } \\
(M W)\end{array}$ \\
\hline Hale & TANESCO & 1967 & 2017 & Hydro & 21 \\
\hline Nyumba ya Mungu & TANESCO & 1968 & 2018 & Hydro & 8 \\
\hline Kidatu & TANESCO & 1975 & 2025 & Hydro & 204 \\
\hline Zuzu diesel & TANESCO & 1980 & 2015 & Diesel & 7.4 \\
\hline Mtera & TANESCO & 1988 & 2038 & Hydro & 80 \\
\hline Tanwat & SPP/IPP & 1995 & 2029 & Biomass & 2 \\
\hline Pangani Falls & TANESCO & 1995 & 2045 & Hydro & 68 \\
\hline Kihansi & TANESCO & 2000 & 2050 & Hydro & 180 \\
\hline Tegeta IPTL & IPP unit & 2002 & 2021 & HFO & 103 \\
\hline Songas5 & IPP unit & 2004 & 2024 & NG & 38 \\
\hline Songas1-4 & IPP unit & 2004 & 2024 & NG & 114 \\
\hline Songas6 & IPP unit & 2006 & 2024 & NG & 37 \\
\hline Tegeta GT & TANESCO & 2009 & 2028 & NG & 45 \\
\hline TPC & SPP/IPP & 2010 & 2030 & Biomass & 17 \\
\hline Ubungo I & TANESCO & 2008 & 2026 & NG & 102 \\
\hline Aggreko Tegeta & Aggreko, rental & 2011 & 2014 & Gas oil & 50 \\
\hline Aggreko Ubungo & Aggreko, rental & 2011 & 2015 & Gas oil & 50 \\
\hline Symbion Ubungo & Symbion, rental & 2011 & 2015 converted & NG/Jet & 126 \\
\hline Mwenga & SPP/IPP & 2012 & 2030 & Hydro & 4 \\
\hline Symbion Arusha & Symbion, rental & 2012 & 2014 & Diesel & 50 \\
\hline Symbion Dodoma & Symbion, rental & 2012 & 2014 & Diesel & 55 \\
\hline Ubungo II & TANESCO & 2012 & 2031 & NG & 105 \\
\hline Nyakato/Mwanza & TANESCO & 2013 & 2038 & HFO & 63 \\
\hline Kinyerezi I & TANESCO & $2015-16$ & & NG & 150 \\
\hline \multicolumn{5}{|c|}{ Total installed capacity (-) rentals (205 MW) } & 1474 \\
\hline \multicolumn{6}{|c|}{$\begin{array}{l}\text { Note: Off-grid and grid-connected together total } 1528 \mathrm{MW} \text {. Grid alone accounts for } 1474 \mathrm{MW} \text {. EPPs/rentals not included in these } \\
\text { totals as have since been retired. HFO = heavy fuel oil; IPP = independent power project; IPTL = Independent Power Tanzania } \\
\text { Ltd.; MW = megawatts; NG = natural gas; SPP = small power projects; TANESCO = Tanzania Electric Supply Company; TPC = } \\
\text { Tanganyika Planting Corporation. }\end{array}$} \\
\hline
\end{tabular}

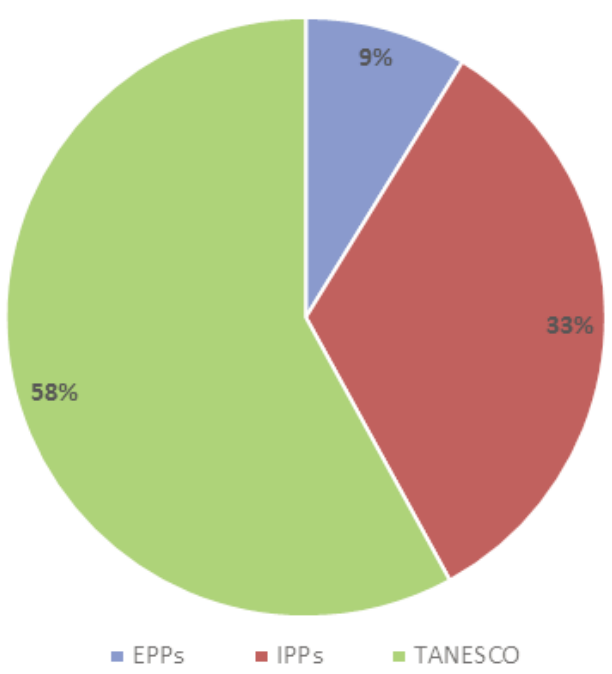

EPPs = emergency power plants; IPTL = Independent Power Tanzania Ltd; TANESCO = Tanzania Electric Supply Co. Symbion Ubungo included in EPP tally.

Figure 2: Share of grid-generated electricity production, by type of producer: Tanzania, 2015 (TANESCO, 2016).

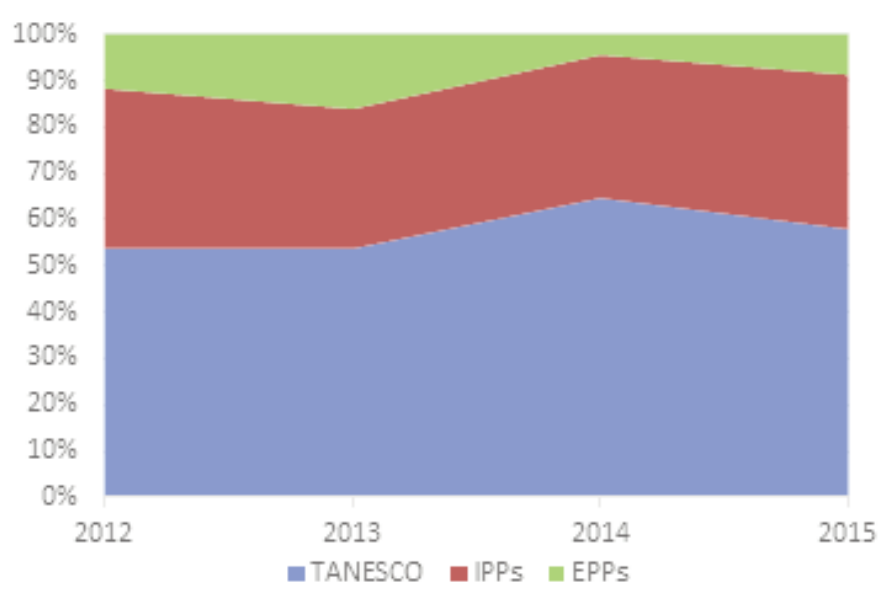

EPPs $=$ emergency power plants; IPTL $=$ Independent Power Tanzania Ltd; TANESCO = Tanzania Electric Supply Co. Symbion Ubungo included in EPP tally.

Note: Excluding less than $1 \%$ in imports and small private producers Tanwat, TPC, and Mufindi.

Figure 3: Share of grid-generated electricity production, by type of producer, 2012-2015. (TANESCO, 2016) 
Table 3: Shares/costs of capacity and generation, by type of producer, in Tanzania, 2015.

(TANESCO, 2016; Songas, 2015; EWURA, 2016)

\begin{tabular}{lccccc}
\hline Entity & 2015 production & \% of production & Total cost (USD) & \% of cost & Per unit cost \\
\hline TANESCO & 3472382.55 & 57.97 & 347238.26 & 44.14 & 0.10 \\
Songas & 1349195.30 & 22.52 & 67459.77 & 8.19 & 0.05 \\
EPPs & 523901.10 & 8.75 & 209560.44 & 25.43 & 0.40 \\
IPTL & 644525.70 & 10.76 & 199802.97 & 25.25 & 0.31 \\
\hline Total & 5990004.66 & 100.00 & 824061.43 & 100.00 & 0.13 \\
\hline Notes: & \multicolumn{7}{l}{ TANESCO's average derived cost excludes the cost of capital. EPPs = emergency power plants; IPTL = Independent Power } \\
Tanzania Ltd.; kWh = kilowatt-hour; SPPs = small power projects; TANESCO = Tanzania Electric Supply Company. Off-grid, \\
imports, SPPs, (Tanwat, TPC, and Mwenga) all excluded from these tallies. The associated off-grid cost is \$0.328, albeit representing \\
only 5 percent of the total generation.
\end{tabular}

2016 (Tsh $274.9 / \mathrm{kWh}$ ) of $1 \%$ ) or approximately USD 0.12 based on average 2016 exchange rates. In 2015, this figure was approximately USD $0.13 / \mathrm{kWh}$. Table 3 shows how each entity contributes to the production and price mix.

If EPPs are removed from Table 3, the average cost of supply falls to approximately USD $0.10 / \mathrm{kWh}$, evidence of EPPs' impact on price. However, such snapshots do not reflect the full reality of the costs involved. In the case of TANESCO, for which a per plant cost is not available, the per unit cost listed in Table 3 is solely a function of TANESCO's running costs and does not include depreciation or finance costs. Unlike for IPPs (Songas and IPTL), electricity users are not paying for any portion of the capital costs of the TANESCO-owned plant, which are governmentsubsidised. These costs are, however, still incurred and are generally paid by taxpayers. It remains a challenge to determine TANESCO's actual costs, including all capital-related expenditure and financing, and to compare these systematically with those of private plants using similar technology at comparable load factors. If the capacity charge component of a plant's tariff is USD $0.4 / \mathrm{kWh}$ at 90 percent plant load factor (PLF), it would be USD 2.4/kWh at 15 percent PLF; that is, the differences in headline tariff arising from the PLF may be substantial.

Songas, whose contribution to generation is second to that of TANESCO, has a different price structure. Its per kilowatt-hour all-inclusive charge comes to approximately USD 0.05 . The average variable charge, a function of competitively priced domestic gas, amounts to a fraction of this total cost, namely USD $0.012-0.013 / \mathrm{kWh}$; this is significantly better than TANESCO's running cost (Table 4).

IPTL resembles Songas in its cost structure as a traditional IPP, and therefore is highlighted here. Capacity charges averaged USD $0.08 / \mathrm{kWh}$ from 2013-2015, almost double Songas' total cost. Taking into consideration differences in technology, this figure appears to be possibly inflated (causes associated with load factors but also with nontransparent procurement will be further observed in the next section). Of the remaining USD $0.23 / \mathrm{kWh}$ in charges for IPTL, USD $0.22 / \mathrm{kWh}$ is accounted for by the imported fuel variable charge, which is a complete pass-through item. Thus, the overwhelming cost of this IPP is for fuel. While the total unit charge for IPTL is six times greater than that of Songas, it is on par with the running costs of TANESCO's Mwanza 60 MW HFO plant, which was financed by the government and came online in 2013. The current unit running cost of the Mwanza plant is USD $0.23 / \mathrm{kWh}$, excluding the repayment of loans and interest, which has yet to be finalized between TANESCO and the government of Tanzania.

Table 4: Comparison of costs, by type of producer, in Tanzania, 2013/5 (USD/kilowatthour). (Authors' compilation based on correspondence with TANESCO stakeholders (2014).)

\begin{tabular}{lccc}
\hline & $\begin{array}{c}\text { Running/ } \\
\text { fuel cost }\end{array}$ & $\begin{array}{c}\text { Capacity } \\
\text { cost }\end{array}$ & $\begin{array}{c}\text { Total } \\
\text { cost }\end{array}$ \\
\hline TANESCO & 0.10 & $\mathrm{~N} / \mathrm{A}$ & $\mathrm{N} / \mathrm{A}$ \\
Songas & 0.013 & 0.037 & 0.05 \\
Ind. Power Tanzania & 0.22 & 0.08 & 0.31 \\
Emergency power plants & 0.29 & 0.11 & 0.40 \\
\hline Total / weighted average & & \multicolumn{3}{c}{ USD 0.13} \\
\hline
\end{tabular}

The five EPPs contributed 16 percent of the generation pie in 2015; however, their costs were 25 percent of the total; IPTL meanwhile, at only 10 percent of production, amounted to 25 percent of total costs. In summary, despite incomplete data on costs, the system was out of balance: EPPs and IPTL accounted for an inordinate portion of costs until recently, relative to their actual production. This was significantly caused by imported fuel charges. It was anticipated that if the debt incurred by the EPPs were to be paid off, TANESCO would break even (EWURA, per. comm., February 28, 2015).

Songas measures up to TANESCO's plants in relation to capacity factors and excels in terms of lower prices, which signals some positive developments in terms of private power (but here, too, there 
have been issues, as mentioned briefly in the supplementary file). For more information on the existing IPPs, please see the supplementary file.

\subsection{Future projects, public and private}

With private developments beset with challenges related to planning and other issues, how does the public sphere fare, especially with a cash-strapped utility? Is private investment being crowded out? As mentioned earlier, TANESCO maintains a dominant share in generation - 58 percent of installed capacity, the majority of which has been built since 2000. In addition, PPPs have been identified as the way forward, with TANESCO being a participant. Thus, the trend has been to expand, not curtail, state-owned assets, despite repeated calls for increased private sector participation. In 2014, four of the six priority generation projects in the near term (that is, to be completed before or by 2018) were expected to be owned by TANESCO, with varying degrees of PPPs and associated funding; these four projects were Kinyerezi I-IV (with recently completed Kinyerezi I, and Kinyerezi II specified for government funding and Kinyerezi III and IV identified for PPP funding, with Chinese partnerships) (Table 5).

Of the estimated USD 1.91 billion earmarked for investment in the generation projects noted earlier, the government was expected to contribute USD 615 million, approximately 32 percent, of the new capacity. Thus, while ownership of assets would be dominated by TANESCO in the near term, funding was to be supplemented - notably by the Chinese (as discussed in greater detail below) and IPPs including local IPP sponsors.

The tariff for each of these projects has yet to be announced. For Kinyerezi I and II, which are financed directly by the government, the government must determine whether there will be on-lending or equity shares provided to TANESCO. Kinyerezi III and IV, which are PPPs, are still in negotiations and the tariff remains undecided. It has been indicated that for gas-fired plants the total unit cost should not exceed USD 0.08/kWh; however, this is highly dependent on gas prices and still does not reflect the critical capital component, which calls into question the true efficacy of the publicly procured plant.

It is important to note that, as of 2015, Kinyerezi II, III, and IV encountered delays, which still persist. The completion date of 2018 is therefore no longer considered realistic. The following issues have been cited as impediments: a lack of serious developers, a lack of funding potential, a lack of credit enhancement mechanisms, the viability of the power offtaker (TANESCO), and the availability of certain types of fuel (Eberhard et al., 2016).

Parallel to this expansion, the goal (at least on the books) is to achieve retail competition and the privatisation of TANESCO. The year 2024 has been identified for preparing generation and distribution companies for listing and privatizsation. Thus, state ownership will probably continue in the near term (albeit with a larger portion of supplementary funding), but in the longer term a phasing out of direct public ownership and asset funding is expected. Nonetheless, there seems to be a real disconnect between plans and action, and the necessary buyin to realise the plans.

\subsection{Further gas sector and power develop- ments: The government looks east}

In the meantime, the availability (or not) of domestic natural gas continues to play a pivotal role in determining outcomes in the power sector. The government sought private participation in the development of the Mnazi field for over six years, but no viable interest was found, due in part to a low level of proven reserves in the field and a limited investment-enabling environment. Meanwhile the Songo Songo fields were slated for expansion by the private sector to meet the near-term needs of

Table 5: Generation projects planned in the near term in Tanzania (NKRA Energy Lab, 2013; TANESCO, 2015).

\begin{tabular}{lcccccc}
\hline Ownership & Project name & $\begin{array}{c}\text { Capacity } \\
(\mathrm{MW})\end{array}$ & Tech/ Fuel & $\begin{array}{c}\text { Investment } \\
\text { (USD millions) }\end{array}$ & Funding source & $\begin{array}{c}\text { Status } \\
\text { (4Q2016) }\end{array}$ \\
\hline TANESCO & Kinyerezi I & 150 & OCGT & 183.3 & GoT & Done \\
TANESCO & Kinyerezi II & 240 & CCGT & 432 & GoT & Construction \\
TANESCO & Kinyerezi III & 300 & OCGT & 389.7 & PPP & Not started \\
TANESCO & Kinyerezi IV & 450 & CCGT & 400 & PPP & Not started \\
IPP & Kilwa Energy & 308 & CCGT & 365 & ETG POWER, UAE & Not started \\
IPP & Singida & 50 & Wind & 136 & National Devt Corp, TANESCO, & On hold \\
& Wind East Africa & 100 & Wind & 285 & Aldwych, IFC, Six Telecoms & Not started \\
\hline IPP & Wower Pool East Africa Ltd
\end{tabular}

Note: 210 MW OCGT cited in NKRA (2013), revised to 308 MW (2015); 210 MW is for OCGT to operate for two years, thereafter expanded to CCGT. CCGT = combined-cycle gas turbine; ETG = Export Trading Group; GoT = Government of Tanzania; IFC = International Finance Corporation; IPP = independent power plant; MW = megawatts; OCGT = open-cycle gas turbine; PPP = public-private partnership; TANESCO = Tanzania Electric Supply Company; UAE = United Arab Emirates. 
the country's gas supply, approximately 50 million standard cubic feet per day (mmscfd) of gas to power 250-300 MW (single cycle). A deal was negotiated with Pan African Energy Tanzania Ltd, the existing developer, for a gas infrastructure expansion in 2011 (which had a tariff approved by EWURA; a signed engineering, procurement, construction contract; and financing arranged).

On the cusp of the Songo Songo expansion, Tanzania engaged China to help fund natural gas infrastructure connecting Mnazi Bay and Songo Songo to Dar-es-Salaam, also known as the National Natural Gas Infrastructure Project (NNGIP). As a result, the government put the Songo Songo expansion on hold and focused on the development of the Mnazi field, which was reconfigured from a private infrastructure project to one led by the public sector. Gas deliveries from Songo Songo were estimated to be able to feed (and were earmarked for) near-term power generation, even as the government sought longer-term gas supply. This shift, from near-term Songas expansion to the long-term NNGIP, exacerbated a gap that was plugged in part by the continued use of EPPs.

The NNGIP, which includes a $532 \mathrm{~km}$ natural gas pipeline from Mtwara to Dar-es-Salaam and gas-processing plants, was completed in 2015 and should be sufficient to run all the plants in an ideal scenario. Despite its mega capacity of $784 \mathrm{mmscfd}$ (1002 mmscfd compressed), the Mtwara-Dar pipe initially had only about 80 mmscfd of gas entering it from Mnazi Bay for a limited period, about enough to run 350-450 MW (that is, slightly more than what the Songo Songo expansion could have provided for near-term developments). While it is expected that more reserves may be proven and supplies increased, presently that is not part of the gas contract. Most of the gas is expected to be consumed by the existing gas turbine plants (including Kinyerezi I, TANESCO's Jacobsen 120 MW at Ubungo, Siemens gas turbines, and the extended Symbion 40-120 MW, LM6000s and TM2500s). As of end 2016, the pipeline is utilised at 6.5 percent and the gas processing plant, 21 percent.

Tanzania has an impending need for more gas to fuel new projects, but that has proven to be a challenge to date. More information on Tanzania's gas sector development is in the supplementary file.

\section{Conclusions}

The 'Big results now' initiative set a goal of achieving $10000 \mathrm{MW}$ of generation capacity by 2025 , doubling access rates, increasing efficiency, boosting transparency and financial integrity, and privatising generation and distribution assets. The plans were admirable and ambitious, but ultimately unachievable and were scaled back. The government repeatedly committed to reforms but was slow to implement them and has wavered in its commitment to integrate private power sustainably and systematically.

Generally, the sector has suffered from poor governance. Frequent turnover at the Ministry of Energy and Minerals has impeded consistent and robust decision-making. Planning has become a political exercise; coordination, which is intricately linked to planning, has been poor; interagency fighting has been common; and communication among ministries, stakeholders, and donors has, on occasion, broken down, as during the negotiation of Songas and Independent Power Tanzania Ltd (IPTL).

Private power and its benefits are by no means a forgone conclusion in Tanzania. Power projects planned in recent years have been or are going to be built by TANESCO, or at least with significant TANESCO participation, despite its financial situation, and private sector investment is effectively being crowded out. The push to promote public sector projects is not only the result of vested interests, but also of a general antipathy to private sector participation that has at times informed decisionmaking in Tanzania.

The issues at stake go beyond the question of private versus public sector involvement. A lack of competitive procurement and transparent contracting has resulted in costly deals and disputed contracts, with large drains on time and resources. Although Songas and IPTL run on different fuels and are not exactly comparable, Songas is clearly the least-cost privately owned supply option in Tanzania; IPTL is the most expensive. IPTL power costs six times more than Songas' power and just a little less than the emergency power plants' power. Beyond technical considerations, it is apparent that such a large price difference between the two is primarily due to a lack of competition and the disputes that have affected IPTL procurement. Symbion is another powerful example of a deal initially contracted in a nontransparent manner, with costly and disruptive outcomes. The Energy and Water Utilities Regulatory Agency has been given the mandate to reject unsolicited proposals, like IPTL, that are not within the Power Sector Master Plan and are not financially viable. However, negotiated deals persist, and non-competitive procurement remains the preferred method at the governing level.

Poor planning, interagency disagreements, vested interests, and non-competitive practices have unravelled contracts and impeded the timely procurement of generation. As a result, the country was forced to depend on emergency power plants and expensive oil-fired generation over the past several years.

The supply of natural gas, which is directly tied to electric power development, looks to be a positive story, though not without uncertainties. 
Historically, delays in expanding the gas supply resulted in costly contingency plans, such as emergency power plants, which in turn have led to financial stress for TANESCO. The lack of coordination between expanding gas production, pipelines and power plants continues to be a challenge, despite the construction of the new high-volume Chinesefunded gas pipeline. The delay of the Petroleum (Upstream, Midstream, and Downstream) Act, finally passed in July 2015, also left the gas sector with no consistent regulation for many years.

To address these challenges, private and public stakeholders alike have called for a commitment to improve governance across Tanzania's gas and power sectors in three focus areas. The first is to improve the link between planning and procurement/investment decisions. There have been many instances where electricity generation plans have not resulted in timely initiation of procurement processes for new power with the result that power shortages and non-transparent emergency deals have been repeated. The second is to improve the procurement and contract negotiating processes carried out by the relevant government and parastatal stakeholders. Competitive tenders need to be the norm, not unsolicited offers. Developers have also reported that contract negotiating processes are ineffective and cumbersome, which has often led to extensive delays or potential projects being abandoned. Clear, transparent processes and accountability for contracting with IPPs and engaging with development financiers (including that of Chinese ExIm) need to be prioritised. Thirdly, it is necessary for the government to reestablish its commitment to contracting with IPPs. Of late, most new power projects are being built as TANESCO-owned plants; this puts the government's commitment to attracting private capital into doubt, despite repeated statements to the contrary.

Finally, the sustainability of investment in new power projects relies on TANESCO being a credible and financially viable off-taker, in the absence of further reforms that allows for direct contracts between customers and IPPs. Efforts to improve the performance of TANESCO and to commercialise and unbundle the utility need to be accelerated.

It is to be hoped that a secure gas supply will be established, putting an end to Tanzania's costly dependence on imported fuel. Private power has, largely through Songas, helped benchmark the costs and performance of state-owned generation, and provided much needed new investment. Other projects, such as IPTL and the emergency power plants, have proven to be costly experiments, primarily due to planning and procurement failures. Tanzania does not have sufficient public resources to meet all country's future power needs. It will need to learn the lessons of its prior engagement with independent power producers if it is to attract more private investment in power in the future.

Power sector reform and independent power producers are not ends in and of themselves. Reform is meant to lead the way to a more sustainable sector which provides an increase in capacity and more affordable, reliable electricity. Who, how and what will lead to affordable, reliable power, over the long term in Tanzania? This question can be both asked and answered with the benefit of hindsight, as highlighted in this study, and a new path may be taken.

\section{Note}

1. Supplementary material can be found at https://journals.assaf.org.za/jesa/article/view/4389.

\section{References}

Asia Pacific Economic Cooperation Energy Working Group. 1997. Manual of best practice principles for independent power producers, APEC Secretariat, Canberra.

Castellano, A., Kendall, A., Nikomarov, M. and Swemmer. T. 2015. Brighter Africa. McKinsey \& Company Monthly Journal, February 2015.

Clark, A., Davis, M., Eberhard, A., Gratwick, A. and Wamukonya, N. 2005. Power sector reform in Africa: Assessing the impact on poor People. University of Cape Town Graduate School of Business/ESMAP.

Eberhard, A., Gratwick, K., Morella, E. and Antmann, P. 2016. Independent power projects in sub-Saharan Africa: Lessons from five key countries. World Bank, Washington, D.C. https://doi.org/10.1596/978-1-4648-0800-5

Eberhard, A., Gratwick, K., Morella, E. and Antmann, P. 2017. Independent power projects in sub-Saharan Africa: Investment trends and policy lessons. Energy Policy 108: 390-424. https://doi.org/10.1016/j.enpol.2017.05.023

Eberhard, A. and Gratwick, K.N. 2011. IPPs in subSaharan Africa: Determinants of success. Energy Policy 39: 5541-5549. https://doi.org/10.1016/j.enpol.2011.05.004

Eberhard, A., Rosnes, 0., Shkaratan, M. and Vennemo, H. 2011. Africa's power infrastructure: Investment, integration, efficiency. World Bank, Washington, D.C.

Ghanadan, R. and Eberhard, A. 2007. Electricity utility management contracts in Africa: Lessons and experience from the TANESCO-NETGroup Solutions management contract in Tanzania, 2002-2006. MIR Working Paper, Management Programme for Infrastructure Reform \& Regulation (MIR), Cape Town

Gratwick, K. and Eberhard. A. 2008. Demise of the standard model for power sector reform and the emergence of hybrid power markets. Energy Policy 36: 3948-3960 https://doi.org/10.1016/j.enpol.2008.07.021

Gratwick, K., Ghanadan, R. and Eberhard, A. 2006. Generating power and controversy: Understanding Tanzania's independent power projects, Journal of 
Energy in Southern Africa 17(4):39-56.

Kapika, J. and Eberhard, A. 2013. Power sector reform and regulation in Africa: Lessons from Kenya, Tanzania, Uganda, Zambia, Namibia and Ghana. HSRC Press, Cape Town.

Ministry of Energy and Minerals (MEM). 2013. Joint energy sector review (JESR) 2012/13 for Tanzania. MEM, Dar-es-Salaam.

Ministry of Energy and Minerals (MEM) 2014. Electricity supply industry reform strategy and road map 2014 2015. MEM, Dar-es-Salaam.

Ng'wanakilala, F. 2014. Tanzania to pick winners of oil, gas bids before year-end. Reuters, October 17, 2014. Available at: http://www.reuters.com/article/ 2014/10/17/tanzania-gas-idUSL6NOSC2RS20141017. (Accessed 22 April 2015).

National Key Result Area Energy. 2013. Energy lab final report, NKRA, Dar es Salaam.

Society of Petroleum Engineers. 2011. Guidelines for application of the petroleum resources management system. Available at: http://www.spe.org/industry/ reserves.php\#redirected_from=/industry/reserves/. (Accessed 22 April 2015).

United Republic of Tanzania Audit Office. 2013. Report of the Controller and Auditor General on the financial statements of TANESCO for the year ended 31 December. United Republic of Tanzania Audit Office, Dar-es-Salaam.

World Bank. 1993. The World Bank's role in the electric power sector: Policies for effective institutional, regulatory, and financial reform. World Bank, Washington, D.C.

World Bank and USAID, 1994. Submission and evaluation of proposals for private power generation

projects in developing countries. IEN Occasional Paper No. 2, World Bank, Washington, D.C.

World Bank. 2016. New financing to bring 2.5 Million Tanzanian households to the electricity grid. Available at: http://www.worldbank.org/en/ news/press-release/2016/06/21/new-financing-tobring-25-million-tanzanian-households-to-the-electricity-grid. (Accessed 12 November 2016.) 